\title{
SHOULD THE DOCTRINE OF ULTRA VIRES BE DISCARDED?
}

\author{
Chardes E. Carpenter
}

Should not the doctrine of ultra vires be entirely discarded? Has it not made for complexity and confusion in the law? Is there any sound basis for it, any excuse for its existence? And will its abandonment not leave the law in a more satisfactory state?

Let us consider the condition in which we find the law as it relates to ultra vires, examine into the grounds upon which the doctrine is based and attempt to forecast the result of a complete abandonment of the doctrine.

The powers which a corporation is authorized to exercise are set forth in its charter, or in its articles of incorporation. Statutes, too, may place express prohibitions upon the exercise of certain powers. If the corporation enters into a transaction which is beyond the powers expressly or impliedly contained in the charter or articles of incorporation or in violation of the statutory restriction, the transaction is said to be ultra vires, i. e., beyond the powers of the corporation. What legal consequences are attached to such transactions? The doctrine of ultra vires is the means by which the courts have worked out the answer to this question. The answer is not clear and simple, but contradictory, uncertain, and frequently unjust. Some courts have said the state alone can object, but most courts have gone further and have to a greater or less extent denied validity to the transaction between the parties. It does not seem to be an exaggeration to say that there are no sound theories consistently applied and there are many unsound ones discordantly applied. In the first place there exist two fundamental conceptions as to the nature of a corporation and its powers, diametrically opposed to each other and responsible for much confusion. According to one concept the corporation is an artificial entity deriving its existence and its powers from the state; and according to the other it is a group of persons with general powers acting as a unit in some respects but prohibited from acting as a unit beyond the authority granted.

THE CONDITION OF THE ENGLISH LAW RELATING TO ULTRA VIRES

In Éngland both views prevail. Royal charter corporations have the capacity of natural persons and their contracts though ultra vires are valid. ${ }^{I}$ The Crown, however, has the right to repeal letters patent for entering into ultra vires transactions. ${ }^{2}$ Statutory corporations, that is,

\footnotetext{
${ }^{1}$ See British South Africa Co. v. De Beers [19ro] I Ch. 354, 375.

-See Eastern Archipelago Co. v. The Qucen (I853, K. B.) 2 El. \& B1. 856 and Brice, Doctrine of Ultra Vires (2d. ed. r877) 908.
} 
corporations created by special act of Parliament, or organized under a general act, on the other hand, have no power beyond that granted and their ultra vires contracts are void. ${ }^{3}$ It is difficult to conceive of a sufficient ground for the distinction which the English law takes between royal charter and statutory corporations and little can be said for the soundness or the justice of the law which treats all the ultra vires contracts of statutory corporations as void. Yet this distinction in the English law has not introduced confusion or complexity so far as rights of action on the contract are concerned for all ultra vires contracts of crown corporations are treated as valid and of statutory corporations as void.

THE CONDITION OF THE AMERICAN LAW RELATING TO ULTRA VIRES

On the other hand the American law stands out by contrast in its lack of the merit of easy statement. In speaking of the law of ultra vires Judge Thompson has said :

"After having given a long and attentive study to the subject, the writer affirms that the Anglo-American law with reference to it is in a state of hopeless and inextricable confusion; that contradictory decisions are constantly rendered by the same courts; that opposing principles, tending to contrary results, jostle and crowd each other ... and that the judge seizes upon one of these principles to-day and to-morrow upon another, and enlarges it or applies it according to the seeming exigencies of justice in the particular case."

Machen says, ${ }^{5}$

"The authorities are in utter confusion. No court consistently adheres to either view-the view that a corporation cannot make an ultra vires contract, or the view that ultra vires contracts are illegal. Indeed, difficulty is often experienced in determining upon which theory even in a single case a court has acted. To attempt to unravel the tangle so as to show what rules of law are adopted in each state would be a protracted if not an impossible task."

THE LAW WHERE THE THEORY OF SPECIAL POWERS PREVAILS

In accord with the English conception of the nature of corporate powers as applied to statutory corporations and proceeding upon the theory that the corporation lacks power to make ultra vires contracts there are decisions of the United States Supreme Court, ${ }^{6}$ the other.

${ }^{3}$ Ashbury Ry. Co. v. Riche (1875) L. R. 7 H. L. 653; Great North-West Ry. Co. v. Charlebois [I899, P. C.] A. C. Ir4.

Thompson, The Doctrine of Ultra Vires in Relation to Private Corporation (I894) 28 AM. L. REv. 376. Quoted in Pepper, The Unauthorized or Prohibited Exercise of Corporate Power (I894) 9 HARv. L. REv. 255, 272 with disapproval. "Machen, Modern Law of Corporations (Ig08) sec. Io2I.

'Central Transportation Co. v. Pullman's Car Co. (I89I) I39 U. S. 24, 59, II Sup. Ct. 478,488 
federal courts, ${ }_{7}^{7}$ and of the courts of the states of Alabama, ${ }^{8}$ Illinois, ${ }^{9}$ Maine, ${ }^{10}$ Maryland, ${ }^{11}$ Massachusetts, ${ }^{12}$ Tennessee, ${ }^{13}$ and possibly Vermont ${ }^{14}$ to the effect that ultra vires contracts are void. Thus it has been held that where the corporation has made an ultra vires lease of its property it could not recover rents for the period of occupation, ${ }^{15}$ or against the lessee on the covenants in the lease ${ }^{16}$ that a national bank holding stock in another corporation ultra vires was not subject to the statutory double liability of stockholders, ${ }^{17}$ nor subject to being assessed as a shareholder though it is receiving the dividends ${ }^{18}$ that an insurance contract not executed according to the provisions of its charter ${ }^{10}$ and a note given for the purchase of a steamboat ultra vires ${ }^{20}$ were void. On this theory, where the contract was ultra vires it has been held that there coill be no recovery on a contract of guaranty, ${ }^{21}$ or an action maintained for the price of goods sold, ${ }^{22}$ or for money loaned, ${ }^{23}$ or the balance due upon the purchase of shares. ${ }^{24}$

"National Trust \& Credit Co. v. Orcutt \& Son Co.. (I9I9, C. C. A. 7th) 259 Fed. 830; Lewis v. Fifth-Third National Baık (I92I, C. C. A. 6th) 274 Fed. 587;

Wm. Filene's Sons Co. v. Gilchrist Co. (1922, C. C. A. Ist) 284 Fed. 664

${ }^{8}$ See Chewacla Lime Works v. Dismukes, Frierson \& Co. (I888) 87 Ala. 344, 347, 6 So. 122, I23; Steiner v. Steiner (I890) I20 Ala. 128, 14I, 26 So. 494, 497.

'National Home Ass. v. Home Savings Bank (I899) I8r I11. 35, 54 N. E. 6rg; Best Brewing Co. v. Klassen (I900) I85 Ill. 37, 57 N. E. 20, 50 L. R. A. 765; Calumet Co. v. Conkling (I916) 273 I11. 3r8, II2 N. E. 982; Mercantile Trust Co. v. Kastor (Ig16) 273 I11. 332, II2 N. E. 988.

${ }^{10}$ Brunswick Gas Light Co. v. United Gas Co. (1893) 85 Me. 532, 27 Atl. 525.

${ }^{11}$ Western Maryland R. Co. v. Blue Ridge Co. (Ig05) I0z Md. 307, 62 Atl. 35I. But cf. Black v. First National Bank (I903) 96 Md. 399, 54 At1. 88.

${ }^{12}$ Davis v. Old Colony R. Co. (I88I) I3I Mass. 258. But contra: Slater Woolen Co. v. Lamb (I886) I43 Mass. 420, 9 N. E. 823.

${ }^{13}$ Marble Co. v. Harvey (I892) 92 Tenn. II5, 20 S. W. 427 ; Miller v. Ins. Co. (1893) 92 Tenn. 167,21 S. W. 39. But $c f$. Tennessee Ice Co. v. Raine (rgor) Io7 Tenn. I5I, 64 S. W. 29.

${ }^{14}$ Metropolitan Stock Exch. v. National Bank (1903) 76 Vt. 303, 57 Atl. Ior.

${ }^{15}$ Central Transportation Co. v. Pullman's Car Co., supra note 6; McCormick v. Market Bank (1897) I65 U. S. 538, I7 Sup. Ct. 433 . See Thomas v. $R$. $R$. Co. (I880) I0I U. S. 7I, 86.

"Brunswick Gas Light. Co. v. United Gas Co., supra note io.

${ }^{17}$ California Bank v. Kennedy (I897) I67 U. S. 362, I75 Sup. Ct. 831 ; Cancord First National Bank v. Hazekins (I899) I74 U. S. 364, I9 Sup. Ct. 739; First National Bank of Ottawa v. Converse (Ig06) 200 U. S. 425, 26 Sup. Ct. 306; Merchants' Bank v. Wehrmann (I906) 202 U. S. 295, 26 Sup. Ct. 613; contra: National Bank v. Case (I878) 99 U. S. 628.

${ }^{18}$ Shaw v. National German American Bank (1904, C. C. A. 8th) I32 Fed. 658.

${ }^{20}$ Head \& Amory v. The Providence Ins. Co. (1804, U. S.) 2 Cranch, I27.

${ }^{20}$ Pearce v. The Madison \& Indianapolis R. Co. (1858, U. S.) 21 How. 44I.

"Best Brewing Co. v. Klassen, supra note 9; Davis v. Old Colony $R$. Co., supra note I2; Western Maryland $R$. Co. v. Blue Ridge Co., supra note II; William Filene's Sons Co. v. Gilchrist Co., supra note 7.

${ }_{22}$ Chewacla Lime Works v. Dismukes, Frierson \& Co., supra note 8.

${ }^{23}$ Mercantile Trust Co. v. Kastor, supra note 9.

"Marble Co. v. Harvey, supra note I3. 
Perhaps the clearest and the strongest statement of this view is to be found in the opinion of Justice Gray of the United States Supreme Court in the case of Central Transportation Co. v. Pullman's Car Co. ${ }^{25}$ where he said:

"A contract of a corporation which is ultra vires in the proper sense, that is to say, outside the object of its creation as defined in the law of its organization, and therefore beyond the powers conferred upon it by the legislature, is not, voidable only, but wholly void, and of no legal effect. The objection to the contract is, not merely that the corporation ought not to have made it, but that it could not make it. The contract cannot be ratified by either party, because it could not have been authorized by either. No performance on either side can give the unlawful contract any validity, or be the foundation of any right of action upon it."

It is obvious that it is impossible consistently with this theory of special capacities, or absence of all capacity beyond intra vires transactions to treat ultra vires contracts other than as void. These courts have recognized this. In National Home Association v. Bank, the court, in speaking of an ultra vires contract, said: $:^{26}$

"There would, of course, be no power to confirm or ratify a contract of that kind, because the power to enter into it is absolutely wanting. If there is no power to make the contract there can be no power to ratify it, and it would seem clear that the opposite party could not take away the incapacity and give the contract vitality by doing something under it. It would be contradictory to say that a contract is void for an absolute want of power to make it and yet may become legal and valid as a contract, by way of estoppel, through some other act of the party under such incapacity, or some act of the other party chargeable by law with notice of the want of power."

Yet these courts which have approved the emphatic language of Justice Gray in the Pullman case and have held ultra vires contracts void because the corporation had no power to make them, have taken a squarely contrary position and have made many decisions upholding the validity of ultra vires contracts. They have held that where a corporation has taken property real or personal as security ultra vires, ${ }^{27}$ or where the corporation has been a conduit of title ultra vires, ${ }^{28}$ or where

\footnotetext{
${ }^{25}$ Supra note 6, at p. 59, II Sup. Ct. at p. 488.

${ }^{2}$ Supra note 9, at p. 44,54 N. E. at p. 62 I.

${ }^{2 \pi}$ Schuyler Nat. Bank v. Gadsden (I903) IgI U. S. 45I, 24 Sup. Ct. I29; Nat. Bank v. Matthews (I878) 98 U. S. 62I; Nat. Bank v. Whitney (I880) 103 U. S. 99; Nat. Bank v. Stewart (1882) Io7 U. S. 676, 2 Sup. Ct. 778 (after stock unlawfully accepted had been sold, no recovery of proceeds); Logan Cty. Bank v. Tormsend (I89x) I39 U. S. 67, II Sup. Ct. 496; see Jones v. Guaranty \& Indemnity Co. (1880) Ior U. S. 622, 628; Reynolds v. First Bank of Crawefordsville (I884) II2 U. S. 405, 4I3, 5 Sup. Ct. 2I3, 2 I7.

${ }^{23}$ Kerfoot v. Farmers Bank (1910) 218 U. S. 28I, 3I Sup. Ct. I4; see Blair v. City of Chicago (I905) 20r U. S. 400, 450, 26 Sup. Ct. 427, 436; Lantry v. Wallace (I900) I82 U. S. 536, 2 I Sup. Ct. 878; Fritts v. Palmer (I889) I32 U. S. 282, Io Sup. Ct. 93 .
} 
the grantor or his heirs attack the title to the property conveyed ultra vires to the corporation, ${ }^{29}$ the title of the corporation or its grantee to the property is valid and the state alone can object. There are decisions of these courts, too, that a corporation doing an ultra vires business cannot escape $a$ tax on that business ${ }^{30}$ and that a corporation which was holding stock in another corporation ultra vires ${ }^{31}$ could not escape the statutory double liability imposed upon stockholders. The language in many of the opinions of these courts, no less emphatically than their decisions, contradicts the view that the corporation's contract is void because the corporation had no power to make it. These courts have said: "It (the ultra vires contract) is valid until assailed in a direct proceeding instituted for that purpose." ${ }^{22}$ And it is a matter "between the government of the State .... and the corporation, and is no concern of the defendant." "Restrictions .... upon the amount of property it may hold cannot be taken advantage of collaterally by private persons, but only in a direct proceeding by the state which created it." "When a party sells and conveys property to a corporation, which is without power to purchase and hold the same, and receives compensation therefor ... the question becomes one between the corporation and the state." "Corporations ... " will be estopped from denying that they had authority to make such contracts." "A "A contract simply ultra vires is not necessarily unenforcible. It may be enforced under certain conditions." "37 And "it may be considered settled law to-day that where a corporation goes outside of its legitimate business and makes a contract, and the contract is executed and the corporation has received the benefits of the contract, the courts will never listen to a plea of ultra vires." 38

It is not only true that the law of those jurisdictions which adopt the doctrine of special powers is incapable of reconciliation with that doctrine but it seems also impossible to explain, classify, or reconcile the decisions of those jurisdictions with any existing theory or com-

${ }^{2}$ American \& Foreign Christian Union v. Yount (I879) Ior U. S. 352; Jones v. Habersham (1882) 107 U. S. I74, 2 Sup. Ct. 336; see Reynolds v. Bank of Crawfordsville, supra note 27.

${ }^{30}$ Salt Lake City v. Hollister (I885) II8 U. S. 256, 6 Sup. Ct. 1055.

"See Nat. Bank v. Case, supra note I7, but see also other cases there cited.

Nat. Bank v. Matthews, supra note 27 , at p. 628 .

${ }^{3}$ Cowell $v$. Springs Co. (1879) 100 U. S. 55, 60. The corporation here was allowed to hold real estate necessary to conduct its business; it was argued that the land in question was not such.

s Jones v. Habersham, supra note 29 , at p. 188,2 Sup. Ct. at p. 348 .

${ }^{*}$ Long v. Georgia Pacific Ry. Co. (I890) 9r Ala. 519, 522, 8 So. 706, 707.

${ }^{36}$ Chicago Building Soc. v. Crowell (I872) 65 I1l. 453, 459.

${ }^{37}$ Maryland Trust Co. v. Mechanics' Bank (I906) I02 Md. 608, 615, 63 Atl. $70,72$.

${ }^{3}$ Holt v. Winfield Bank (1885, C. C. D. Kan.) 25 Fed. 812, cited with approval in Tennessee Ice Co. v. Raine, supra note 13 , at $156,64 \mathrm{~S}$. W. at p. 30. 
bination of theories relating to ultra vires. The distinction between executory and executed ultra vires contracts which obtains in most of the states will not afford a basis for classifying these decisions. Some of these courts expressly repudiate the distinction between executory and executed contracts, as we saw in the National Home Association case previously quoted. Other cases have adopted that distinction as the ground of their decisions. Thus in the Oregon Ry. Co. v. Oregonian $R y . C o .,^{39}$ an action by the lessor for the rent payable in advance on a lease for ninety-six years, where the lessee had been in possession for three years and had paid his rent for the period of occupation, the court said:

"To say that a contract which runs for ninety-six years, and which requires of both parties to it continual and actual operations and performance under it, becomes an executed contract by such performance for less than three years of the term, is carrying the doctrine much further than it has ever been carried, and is decidedly a misnomer. This class of cases is not governed by the doctrine of part performance."

Is it not impossible, too, to reconcile consistently with this distinction the decisions of the United States Supreme Court holding an ultra vires lease void where the lessee has been sued for rent for the period of occupation, ${ }^{40}$ and the cases holding an ultra vires conveyance by way of security valid; ${ }^{41}$ or to explain those decisions which hold that a corporation holding stock in another corporation ultra vires is not subject to a statutory double liability, ${ }^{42}$ but that a corporation doing an ultra vires business is liable to a tax on the business ${ }^{43}$ on the ground that the executed contract is a foundation of liabilities while an executory one is not? The confusion reaches a climax in St. Louis, V. \& T. H. R. v. Terre Haute R.44 and the Pullman's Car Co. v. Central Transportation Co. ${ }^{45}$ In the Terre Haute case the court said: ${ }^{46}$

"While an unlawful contract, the parties to which are in pari delicto, remains executory, its invalidity is a defense in a court of law; and a court of equity will order its cancellation only as an equitable mode of making that defense effectual."

"When the parties are in pari delicto, and the contract has been fully executed on the part of the plaintiff, by the conveyance of property or by the payment of money, and has been repudiated by the defendant, it is now equally well settled that neither a court of law nor of equity

${ }^{30}$ (I888) 130 U.'S. I, 37, 9 Sup. Ct. 409, 417.

${ }^{40}$ See supra note 15.

"See supra note 27.

See supra note I7.

43 Seo supra note 30.

4* (I891) I45 U. S. 393, I2 Sup. Ct. 953.

"s (I898) I7x U. S. I38, I8 Sup. Ct. 808.

${ }^{43}$ Supra note 44, at p. 407, I2 Sup. Ct. at p. 957. 
will assist the plaintiff to recover back the property conveyed or the money paid under the contract."

In the Pullman case the court allows recovery in equity for the reasonable value of the property which has ceased to exist in specie, and says: $:^{47}$

"The right of recovery must rest upon a disaffirmance of the contract, and it is permitted only because of the desire of the courts to do justice as far as possible to the party who has made payments or delivered property under a void agreement and which in justice he ought to recover."

THE LAW WHERE THE THEORY OF GENERAL POWERS PREVAILS

When we come to those jurisdictions which are free from the confusion resulting from maintaining two contradictory conceptions as to the nature of corporate powers and which take the view that the corporation has general powers but is forbidden to act beyond the authority granted it is more nearly possible to classify the decisions. If the contract is executory it is invalid, neither party can enforce it. ${ }^{48}$ This is the law in all the American states except Kansas where there is a strong opinion in a case holding squarely that the executory contract is valid. ${ }^{40}$ Where the contract is fully executed on both sides practically all courts adopting the general capacity theory of the corporation, hold the contract valid and the foundation of rights and liabilities. ${ }^{50}$ Where the contract has been wholly executed by the plaintiff, whether that be the corporation or the other party, and the performance has resulted in benefits to the defendant, the defendant cannot plead ultra vires and

\footnotetext{
${ }^{47}$ Supra note 45, at p. I5I, I8 Sup. Ct. at p. 8r3.

4 See I4a C. J. sec. 2166, note 74; Machen, op. cit. supra note 5, sec. 1058.

"Harris v. Gas Co. (I907) 76 Kan. 750, 92 Pac. II23.

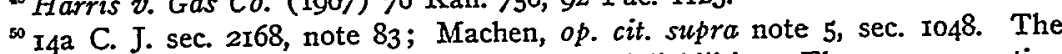
executed contract is a foundation of rights and liabilities. Thus a corporation which has purchased stock in another corporation ultra vires may maintain an action to recover dividends that have been declared. Bigbee \& $W . R$. Packet Co. v. Moore (I\&98) I2I Ala. 379, 25 So. 602. A corporation which has become a member of a partnership ultra vires will not be exempted from liability for partnership debts after the insolvency of the partnership to the prejudice of its creditors. Wallerstein v. Ervin (I90I, C. C. A. 3d) I12 Fed. 124.

Devises, legacies and conveyances in excess of the amount the corporation is authorized to hold or for ultra purposes being an executed transaction is treated by most courts as valid and only subject to objection by the state. Miller $v$. Flemingsburget Turnpike Co. (1900) 22 Ky. Law 1039, 59 S. W. 512 ; De Camp v. Dobbins (1878, Ch.) 29 N. J. Eq. 36, questioned but affirmed in (1879) 3 I N. J. Eq. 67I; Farrington v. Putnam (1897) 90 Me. 405, 37 Atl. 652; Hanson v. Little Sisters of the Poor (1894) 79 Md. 434, 32 At1. ro52. Re Strickney's Will (I897) 85 Md. 79, 36 At1. 654 .

But there is reputable authority to the effect that the corporation cannot acquire a good title where it exceeds its charter limits. Re McGraw (I888) III N. Y. 66, Ig N. E. 233 ; Cornell Univ. v. Fisk (1890) I36 U. S. 152, 1o Sup. Ct. 775; House of Mercy v. Davidson (1897) 90 Tex. 529, 39 S. W. 924 (only in case of devise); Wood v. Hammond (I888) I6 R. I. 98, I7 Atl. 324, I8 Atl. I98.
} 
escape liability. ${ }^{51}$ When we go beyond this, however, and get into the

${ }^{51}$ Leon v. Citizens Bldg. \& Loan Assn. (Igr2) I4 Ariz. 294, I27 Pac. 72I; Minneapolis F. \& $M$. Ins. Co. v. Norman (1905) 74 Ark. I90, 85 S. W. 229.

But see North American Union v. Johnson (1920) I42 Ark. 378, 219 S. W. 769 ; Bay City Bldg. \& Loan Assn. v. Broad (Ig02) I36 Calif. 525, 69 Pac. 225; Lilylands Canal \& Reservoir Co. v. Wood (1913) 56 Colo. 130, I36 Pac. 1026; Denver Fire Ins. Co. v. McClelland (1885) 9 Colo. II, 9 Pac. 77I; In re Litchfield Co. Agricultural Soc. (I917) 91 Conn. 536, 100 Atl. 356; Neillsville Bank v. Tuthill (1886, Dak.) 30 N. W. 154; McQuaig v. Gulf Naval Stores Co. (1908) 56 Fla. 505, 47 So. 2; First National Bank of Wallace v. Callahan Mining Co. (I916) 28 Idaho, 627, I55 Pac. 673; Muncie Gas Co. v. Muncie (1903) 160 Ind. $97,104,66$ N. E. 436, 439; Wright v. Hughes (1889) xIg Ind. 324, 21 N. E. 907 ; Vermont Farm Machinery Co. v. De Soto Co-operative Creamery Co. (1909) I45 Iowa, 49I, I22 N. W. 930; Albin Co. v. Commonwealth (r908) I28 Ky. 295, 108 S. W. 299; Canal \& Claiborne R. R. Co. v. St. Charles Co. (I892) 44 La. Ann. I069, 1075, II So. 702, 704; United German Bank v. Katz (I88I) 57 Md. I4I; Black v. First Nat. Bank of Westminster (1903) 96 Md. 399, 54 At1. 88; Slater Woolen Co. v. Lamb (I886) I43 Mass. 420, 9 N. E. 823; Hall Mfg. Co. v. Anerican Ry. Supply Co. (1882) 48 Mich. 33I, 12 N. W. 205; Dewey v. Toledo \& A. Ry. Co. (1892) 9I Mich. 351, 5I N. W. I063; Timm v. Grand Rapids Brewing Co. (1910) I60 Mich. 37I, I25 N. W. 357 ; Blackwood v. Lansing Chamber of Commerce (1914) I78 Mich. 32I, I44 N. W. 823; Northland Produce Co. v. Stephens (IgII) II6 Minn. 23, I33 N. W. 93; Watts Mercantile Co. v. Buchanan (1908) 92 Miss. 540, 46 So. 66; City of St. Louis v. St. Louis Ry. Co. (1913) 248 Mo. I0, 154 S. W. 55; Schlitz Brewing Co. v. Missouri Poultry \& Grain Co. (Ig2I) 287 Mo. 400, 229 S. W. 813; Latulippe v. New England Invest. Co. (I9I3) 77 N. H. 3I, 86 Atl. 36r; Camden \& Atl. R. R. Co. v. Mays Landing Co. (I886) 48 N. J. I. 530, 7 Atl. 523; Chapman v. Iron Clad Rheostat Co. (1898) 62 N. J. L. 497, 4I Atl. 690; United States Industrial Alcohol Co. v. Distilling Co. (IgI8) 89 N. J. Eq. I77, I04 Atl. 216; Woollard Co. v. City of Albany (r92I, Sup. Ct.) Igo N. Y. Supp. 74I ; Board of Trustees of Charlotte v. Reaity Co. (1903) I34 N. C. 4I, 49, 46 S. E. 723, 725; Tourtelot v. Whithed (I900) 9 N. D. 407, 84 N. W. 8; Clarke v. Olson (I900) 9 N. D. 364,83 N. W. 5I9; Ewing v. Board of Com'rs. Ellis Co. (I9I6) 53 Okla. 250, I56 Pac. 229; Roane v. Union Pac. Life Ins. Co. (r913) 67 Or. 2ं64, I35 Pac. 892; Pittsburgh R. R. Co. v. Altoona R. R. Co. (I900) Ig6 Pa. 452, 46 At1. 43I; Presbyterian Board v. Gilbee (I905) 2I2 Pa. 310, 314, 6r Atl. 925, 926; Lemmon v. East Palestine Rubber Co. (1918) 260 Pa. 28, I03 Atl. 510; Kammer v. Supreme Lodge (1912) 9r S. C. 572,75 S. E. 177; Amer. Nat. Bank v. Wheeler-Adams Auto Co. (Igr3) 3r S. D. 524, I4r N. W. 396; Bond v. Terrell Co. (I89r) 82 Tex. 309, I8 S. W. 69I; Kincheloe Irr. Co. v. Hahn Bros. (I9I2) I05 Tex. 23I, I46 S. W. II87; Bear River Co. v. Hanley (I897) I5 Utah, 506, 50 Pac. 6II; News-Register Co. v. Rockingham Pub. Co. (I9I5) II8 Va. 140, 86 S. E. 874; Spencer v. Alki Point Trans. Co. (rgog) 53 Wash. 77, IoI Pac. 509; McElroy v. Minnesota Co. (1897) 96 Wis. 3I7, 7r N. W. 652; Ledebuhr v. Wisconsin Trust Co. (1902) II2 Wis. $657,662,88$ N. W. 607, 609.

It is perhaps proper in most cases to confine the plaintiff's right to recover on the ultra vires contract to cases where he has completely performed the contract and to deny him relief on the contract partially performed by him.

Western Md. Ry. v. Blue Ridge Hotel Co., supra note II; Day v. Spiral Springs Buggy Co. (1885) 57 Mich. 146, 23 N. W. 628; Mallory v. Hananer Oil Works (1888) 86 Tenn. 598, 8 S. W. 396.

He should have quasi-contractual relief for the benefits bestowed. See Day z. Spiral Springs Buggy Co., supra; Mallory v. Hananer Oil Works, supra. 
field of the partially executed contract where performance has not resulted in benefits to the defendant, ${ }^{52}$ there is less unanimity in the decisions of the courts. Several courts refuse relief to the party contracting with the corporation where he knew or should have known of the unauthorized character of the transaction. ${ }^{53}$ Some courts attach importance to the fact that the stockholders have or have not assented to the transaction. ${ }^{54}$ Others apparently attach no importance to that fact. ${ }^{55}$

\section{THE GROUNDS UPON WHICH ULTRA VIRES RESTS}

Having considered the status of the decisions relating to ultra vires let us now turn to examine the soundness of the grounds upon which the decisions rest. The comparatively few cases in which reasons are given for the decisions afford us a variety of inconsistent bases. The courts have treated ultra vires transactions as void, invalid, or unenforcible upon the following grounds: because the corporation lacked the power to make the contract, ${ }^{58}$ because it was illegal,,$^{57}$ because the party who dealt with the corporation was charged with notice of the limits of the corporation's power, ${ }^{58}$ because the transaction was opposed to the interest of the public that the corporation should not transcend its charter powers, ${ }^{30}$ because it violated the rights of creditors ${ }^{60}$ or of stockholders ${ }^{01}$ not to have the funds of the corporation risked in enterprises not contemplated in the articles of incorporation. Where the ultra vires

22 The courts allowing recovery on the ultra vires contract usually do so on the basis of estoppel and many of them recito the fact of receipt of benefits as the basis of the estoppel. See Martin v. Niagara Falls Co. (I8go) 122 N. Y. 165,25 N. E. 303 (recovery and no benefits).

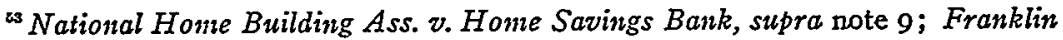
National Bank v. Whitehead (I898) 149 Ind. 143, 49 N. E. 592; Geraghty v. Washtenaw Co. (I906) I45 Mich. 635, 108 N. W. I102; Pittsburgh R. Co. v. Keokuk Bridge Co. (I889) I3I U. S. 37x, 9 Sup. Ct. 770.

Huguenot Mills v. Jempson (1904) 68 S. C. 363, 47 S. E. 687; Martin v. Niagara Falls, supra note 52.

${ }^{35}$ See footnote to Warren, Executory Ultra Vires Transactions in (IgII) 24 HARv. L. REv. 534, 543. See also cases cited in 14 a C. J. sec. 2164 , notes 59 and 58 ; also sec. 2165 .

${ }^{56}$ See supra notes 6 to 14 inclusive.

${ }^{87}$ Machen, op. cit. supra note 5, sec. 1020; Harriman, Ultra Vires Corporation Leases (IgOI) I4 HARv. L. REv. 332 ; Warren, op. cit. supra note 54, at p. 537.

${ }^{3 s}$ Pittsburgh R. Co. v. Keokuk Bridge Co., supra note 53, Atlantic \& Pacific Telegraph Co. v. Union Pac. R. Co. (1880, C. C. D. Neb.) I Fed. 745; Davis v. Old.Colony R. Co., supra note I2; Lucas v. White Line Transfer Co. (1886) 70 Iowa, 542,30 N. W. 77 I.

so supra note 58 .

${ }^{\circ}$ This reason is discussed by Warren, op. cit. supra note 55, at pp. 540 and 54 r.

${ }^{o x}$ Warren, op. cit. supra note 55, at pp. 538 et seq.; Pittsburgh R. Co. v. Keokuk Bridge Co., supra note 53 , at p. 384,9 Sup. Ct. at p. 774 . 
contract is upheld it is usually put upon the ground of estoppel,,$^{62}$ or consideration of fairness between the parties. ${ }^{63}$ Let us now look particularly at these grounds.

\section{Incapacity}

Is the theory of special powers sound or preferable to the theory of general powers? Should the ultra vires contract be treated as void, invalid or unenforcible because the corporation lacked the power to make it? If the corporation is conceived of as deriving its existence and its powers from the state, it is a logical inference that every contract or transaction in excess of the powers granted is void. The concept of special powers is not in itself illogical. ${ }^{.4}$ Neither is there any objection to it on the score of its being difficult to understand or apply or that its consistent application would not give certainty and definiteness to the law. The real objections to it are that it will not explain the actual decisions, even in a single jurisdiction, that it does not represent truly the nature of a corporation, and that it works harsh and unjust results. The law of ultra vires in these jurisdictions which purport to follow the doctrine of special powers cannot be strongly urged as authority for that doctrine or against the doctrine of general powers. In all jurisdictions the liability of corporations for tort is upheld. ${ }^{.5}$ This is true even of the statutory corporation in England where the

${ }^{\infty}$ See supra note 5 I.

${ }^{3}$ Neillsville Bank v. Tuthill, supra note $5 \mathrm{I}$; McQuaig v. Gulf Naval Stores Co., supra note 5I; Dewey v. Railway Co., supra note 5I; Watts Mercantile Co. v. Buchanan, supra note 5I ; Bear River Co. v. Hanley, supra note 5I.

"It has been objected to the doctrine of special powers that, "All rights are in one sense creatures of the law, and it is in a special sense by creation of the law that artificial persons exist at all; but when you have got your artificial person, why call in a second special creation to account for its rights?" Pollock, Contracts (2d Am. ed. I885) I2r. This statement is approved in Harriman, loc. cit. suprä note 54 .

But is not this objection specious? Does the conception of the corporation as an artificial person deriving its powers from governmental fiat call for a second special act of creation? Is there any necessity for assuming that the result of the special fiat of creation must have produced an artificial person with all the legal characteristics of a normal natural person, or with any certain particular characteristics? Natural persons vary in characteristics, for instance, married women and infants do not have all the capacities of adult men. It is not inherently impossible to conceive of both the existence and the capacities, limited or otherwise, as having their origin in the original special act of creation. It is submitted that there is no difficulty in logic with the doctrine of special powers. It should be noted that Pollock's criticism is omitted in the ninth edition (I92I) of his work.

Mason, J., in Harris v. Gas Co. (I907) $76 \mathrm{Kan} .750,752,92$ Pac. Ir23, II24, in speaking of the theory of special capacities, says: "The theory is consistent and logical, but its practical effect is so to circumscribe the power of the court as to make the relief furnished at times inadequate to the occasion."

wachen, op. cit. supra note 5, sec. Io72. 
doctrine of special capacities has been most rigidly adhered to. And is it not apparent that liability in tort is inconsistent with absence of all capacity? The inconsistency of the decisions with the doctrine of special powers is carried further in the United States than in England. In very many cases the United States Supreme Court has not only held the contract valid as between the parties, ${ }^{66}$ but has said that no one but the state can question the validity of the ultra vires undertaking; ${ }^{\text {;r }}$ and there is not a single state that has not upheld the validity of some ultra vires transactions. ${ }^{68}$ Clearly this cannot be done without contradicting the doctrine of special powers. For to grant that a corporation may in some cases or for some purposes validly exercise powers in excess of those granted by the state is to deny that it may not have powers beyond those granted. Consistently with authority, then, the doctrine of special powers cannot stand.

When a group of persons may agree together to form a corporation and decide upon the powers they shall provide for it-and the state is helpless to prevent the formation of the corporation with such powers so long as those persons go through the formality of complying with certain statutory requirements-it seems a little inaccurate to describe the corporation as an entity created by the state and deriving its powers therefrom. The conception of the corporation as a group of persons acting as a legal unit seems to accord more nearly with its real nature. This conception of the corporation, too, has the advantage of allowing flexibility in the treatment of the problem of ultra vires not to be had consistently with the theory of special powers. It does not necessitate the imposition of an inappropriate and harsh penaity for a slight technical omission. It does not require the frequently unjust result of allowing one of the parties to a contract to take unfair advantage of the other. It may best subserve the legitimate interests of the parties concerned.

\section{Illegality}

Can the doctrine of ultra vires rest on illegality? The term illegal applies not only to those contracts which are inimical to social welfare but to those which are prohibited by statute for whatever purpose. ${ }^{69}$

${ }^{\infty}$ Supra notes 27 to 31 inclusive.

or Supra notes 32 to 34 inclusive.

os There is no need to cite cases from the states that follow the doctrine of general powers. Of the states following the doctrine of special powers I cite the following cases which uphold the validity of ultra vires transactions: Long v. Geo. Pacific Ry. Co., supra note 35; Bigbee Packet Co. v. Moore (I899) I2I Ala. 379, 25 So. 602; Bradley v. Ballard (1870) 55 Ill. 4I3; Oakland Elec. Co. v. Union Gas Co. (1910) 107 Me. 279, 78 Atl. 288; Black v. First National Bank, supra note II; Slater Woolen Co. v. Lamb, supra note I2; Preston v. West's Beach Corp. (Ig07) I95 Mass. 482, 8I N. E. 253; Barrow v. Nashville \& Charlotte Co. (1848) 28 Tenn. 304; Heiskell v. Chickasare Lodge (1889) 87 Tenn. 668, II S. W. 825; News-Register Co. v. Rockingham P. Co., supra note 5 I.

"Woodward, Quasi-Contracts (Igr3) sec. I32. 
Under our method of organizing corporations they are impliedly prohibited by statute from making contracts beyond their authorized powers. Ultra vires contracts must then in one sense be considered as illegal. But should the ultra vires contract be treated as an ordinary illegal contract?

The nature of the objection to the ultra vires contract differs fundamentally from the nature of the objection to the illegal contract. The objection to the illegal contract as distinguished from the ultra vires contract relates to the subject matter. The law forbids the actual performance of certain acts because they are opposed to social welfare and the contract to do such acts is obnoxious for that reason. The plaintiff who undertakes to do acts that are inimical to social welfare is a wrongdoer to whom the law denies relief. ${ }^{70} \mathrm{He}$ is a wrongdoer-outside the pale of the law. The objection to the ultra vires contract on the other hand relates to the capacity of the corporation to do such acts, to the fact that the corporation is going beyond the authority given it in the articles of incorporation. There is nothing inimical to social welfare in ultra vires activity in itself. It is absurd to treat the corporation and the party to the ultra vires contract as wrongdoers to whom the law denies relief on the ground that they are engaged in activities that are opposed to the welfare of society.

Illegality will not explain the law of ultra vires. Treating the ultra vires contract as an illegal contract will not give a result that is consonant with the decisions.

It is true that where the contract is still wholly executory or where it is fully executed the results reached by the decisions is the same in the case of the ultra vires contract as it would be in case the action was brought upon an ordinary illegal contract. For in both cases the contracts are unenforcible while still executory, but are effectual if fully executed. But where the contract is neither wholly executory nor fully executed the results reached in these two different classes of cases diverge. This is true whether the action is contractual or quasi-contractual. Where the plaintiff has performed, the majority of the American courts allow recovery on the contract in case of ultra vires ${ }^{71}$ but deny it in case of the ordinary illegal contract. ${ }^{72}$ In some cases the courts seem to have been harsher with ultra vires than ordinary illegal contracts. An innocent plaintiff is allowed to enforce the ordinary illegal contract ${ }^{73}$ but there seems to be no recognition of any rule that a plaintiff may enforce an ultra vires contract because he is innocent.

The quasi-contract relief that is granted in case of ultra vires contracts will not always correspond with the quasi-contract relief that is granted in case of illegal contracts. In case of ultra vires contracts

\footnotetext{
${ }^{70} 3$ Williston, Contracts (1920) secs. 1628, 1630.

"See supra note 5 I.

${ }^{72}$ Woodward, op. cit. supra note 69 , sec. 132 .

${ }^{73}$ Williston, op. cit. supra note 70, sec. I631.
} 
where the plaintiff's performance has resulted in the bestowal of benefits upon the defendant for which he has not given compensation, the courts practically always allow the plaintiff who is not allowed to recover on the contract to recover of the defendant for the unjust enrichment. ${ }^{74}$ In the case of the illegal contract the general rule is that the plaintiff cannot recover for the benefit conferred. ${ }^{75}$ But there are exceptions. If the contract is not malum in se but malum prohibitum the plaintiff, if he was either ignorant of the fact which made the contract illegal, or was not in pari delicto with the defendant or withdrew from the contract before the illegal purpose was accomplished, may recover ${ }^{76}$ While it is true that some cases of ultra vires if treated for that reason as illegal would fall under these exceptions, it is clear that many would not. The relief that is given by the courts quasi-contractually in case of ultra vires action is much broader than is given in case of illegality.

It is undesirable to treat the ultra vires contract as an ordinary illegal one. To deny relief quasi-contractually where benefits have been conferred, as this would require in some cases, is harsh; or to confine the plaintiff in case any relief is granted to relief quasi-contractually is frequently unjust. This is particularly apparent in contracts of guaranty and insurance where the plaintiff pays a comparatively small sum for the undertaking of a risk by the defendant and relying upon having the obligation of the defendant suffers a great loss. Quasi-contract relief will confine him to a recovery of the premiums paid. ${ }^{77}$

It will not do then to rest ultra vires upon illegality. To do so is unsound theoretically and gives us results that are not only incompatible with the decisions but undesirable because unfair.

\section{Notice}

Should the party who contracts with the corporation be barred from recovery on the ultra vires contract upon the ground that he is charged with notice of the limitation of the power of the corporation, as set forth in its charter or articles of incorporation, or as provided by statute?

A comparison of the principles involved in the case of notice of limitations of the authority of an agent or a partner may be helpful here. One who deals with an agent can only hold the principal (aside from estoppel) where the agent has actual authority. The agent's ostensible authority implied from custom and usage may have express limitations upon it, yet the third party who makes a contract with the agent within the ostensible authority, but beyond the express limitations, can hold the principal liable so long as he did not know of these limitations, and acted with ordinary prudence and reasonable diligence and

"Woodward, op. cit. supra note 69 , sec. I60.

"Ibid. sec. 132.

${ }^{75} \mathrm{Ibid}$. secs. 136-I45.

"Denver Fire Ins. Co. v. McClelland, supra note 5 I. 
in good faith, not "wilfully shutting his eyes to restrictions which would otherwise be obvious." "7s This is true of one who makes a contract with one of the partners of a partnership. He is not bound by any limitations imposed upon the ostensible powers of partners in the articles of partnership, unless he has actual notice or fails to act with ordinary prudence or in good faith with respect to such restriction. The notice of limitations upon the power of the corporation that is charged to the party contracting with the corporation goes beyond the notice with which the party who contracts with the agent or partner is charged, in two respects: first, the party contracting with the corporation is charged with the knowledge of the provisions of the articles of incorporation, regardless of whether it is reasonable to do so or not, and he is charged with knowing, at his peril, whether a court will agree with him that the contemplated contract is within its powers-this too when the precedents which are to guide the court in reaching its decision are in the greatest conflict. The unreasonable character of the doctrine has been strongly pointed out by some of the courts. In Denver Fire Ins. Co. v. McClelland, ${ }^{79}$ where it was strongly urged that one dealing with a corporation is bound to know the extent of its powers to contract, Justice Stone replied:

"While as a general proposition this is true, yet it must be conceded that this constructive notice is of a very vague and shadowy character. Every one may have access to the statutes of the states affecting companies incorporated thereunder, and to their articles of incorporation, but to impute a knowledge of the probable construction the courts would put upon these statutes and articles of incorporation to determine questions raised upon a given contract proposed, is carrying the doctrine of notice to an extent which can only be denominated preposterous."

In Bissell v. Michigan Southern R. Co ${ }^{80}$ Judge Comstock concludes his opinion with the observation:

"A traveler from New York to the Mississippi can hardly be required to furnish himself with the charters of all the railroads on his route, or to study a treatise on the law of corporations."

And, second, not only is the party contracting with the corporation charged with knowledge where it is unreasonable to impute it to him, but, unlike the case of principal and agent where the principal assented, he will be unable to hold the corporation liable on the contract, even if all the stockholders assented to the contract. ${ }^{81}$ The vice in the contract is not that a non-assenting principal is bound, but that the contract is bad for illegality, and the plaintiff being charged with notice of the illegal character of the contract is a wrongdoer to whom the law denies relief.

There is this difference between the position of one who deals with

${ }^{3}$ Mechem, Agency (2d ed. 1914) secs. 751-753.

5t Supra note 5I, at p. 22, 9 Pac. at p. 777 .

${ }^{80}$ (I860) 22 N. Y. 258, 28I.

${ }^{67}$ Cases collected, 14a C. J. sec. 2164 , note 59. 
a corporation and one who deals with a partner or an agent. The powers of the corporation are defined in an instrument which is made a matter of public record. But this does not necessarily mean the party dealing with the corporation has actual notice nor is it proper considering the way ordinary business is done to charge the one who deals with the corporation with constructive notice. The objections to constructive notice are well expressed in the quotations from the opinions of Justices Stone and Comstock just made.

It is submitted that in so far as the doctrine of notice in ultra vires contracts goes beyond agency and partnership law, it is unfair, unreasonable, and uncalled for upon any ground of public policy. And it is certainly contrary to the great weight of American authority.

\section{Opposed to Public Policy}

How far is the public, as distinct from the creditors and stockholders of the corporation, interested in the corporation not transcending the limits of its charter? It is important here to distinguish between ultra vires acts which are in themselves inimical to social welfare and those which are free from objection except that they are not authorized. If the acts are objectionable in themselves no doctrine of ultra vires is needed to protect the public. For the transaction will be treated as bad on the ground of public policy either at common law or by statute; in other words the transaction will be treated as illegal in its proper sense. If there is an express statutory prohibition it is clearly a matter for statutory interpretation. Some courts have treated clear and explicit statutory prohibitions upon the making of ultra vires contracts as requiring them to construe the contract as void. ${ }^{82}$ A state may provide that an illegal contract be absolutely void, but even then courts will incline to treat it as voidable and should not treat it as void if any other interpretation is possible. ${ }^{83}$ At any rate the doctrine of ultra vires should not be invoked to interfere with an appropriate interpretation of the statute. In fact all ultra vires transactions might properly be treated as coming under the head of statutory construction, for statutory prohibition express or implied, exists. One learned writer has so treated the question. ${ }^{84}$ But such treatment would be destructive of the prevailing doctrine of ultra vires and would not necessarily involve treating the contract which was not opposed to social welfare as invalid.

If the transaction is one that is not expressly forbidden by statute or objectionable because inimical to public welfare but is merely beyond the powers stipulated for in the articles of incorporation and it is one

${ }^{2}$ Pratt v. Short (1880) 79 N. Y. 437 ; Mutual Guaranty Fire Ins. Co. v. Barker (1899) I07 Iowa, I43, 77 N. W. 868.

${ }^{83} 3$ Williston, op. cit. supra note 70 , sec. I630.

st Pepper, op. cit. supra note 4 . 
which the corporation might enter into free from all possible objection by merely amending its articles to include the otherwise forbidden business, does it not seem wholly untenable to say that in such case the public is interested in the corporation not entering into the ultra vires transaction? If the procedure of allowing amendment to the articles is a guide as to what the state has deemed of public interest it is clear that the state is not interested in the corporation refraining from doing the particular act, but rather that the powers of the corporation be made a matter of public record. To rest the doctrine of ultra vires and to strike down the contract between the parties, frequently to the grievous wrong of one of the parties and to the unfair advantage of the other upon such shadowy and nebulous grounds as public policy seems wholly unwarranted. On the other hand real considerations of public policy as opposed to fanciful ones favor giving validity to the contract. There is the public policy of justice involved in men keeping their contracts. It has been suggested that "public policy is wounded in the deepest sense when the courts of justice educate men in the breaking of their contracts and in the repudiation of their just obligations, on theoretical, speculative and fanciful grounds." 85

Should the state have a right to object to ultra vires transactions? "The rule is still commonly declared to be universal that the exercise of power not reserved in the charter exposes the corporation to quo warranto by the Attorney-General and a judgment of ouster." ${ }_{88}$ There seems to be a tendency to break away from the recognition of an absolute right, if indeed there ever was any such right. It is said that courts may exercise their discretion, ${ }^{87}$ and should not declare forfeiture except for wilful abuse or neglect. ${ }^{88}$ But should not the rule be that where the transaction in question involves activity clearly adverse to a public right or a public interest the state should have a right to interfere and not otherwise? It might be necessary in some instances to provide for such right by statute but the right should exist independently of any question of ultra vires. The mere fact that a corporation acts in excess of its charter powers does not mean that its action is adverse to public interest. To say that there is a public policy in favor of keeping the corporation within its charter. limits is vague ${ }^{89}$ and in most cases is untrue. As to whether the action is adverse to public interest the same test should be applied to the corporate person as to the natural person. If the act is unobjectionable in itself and if no specific public interest is involved why should the state have any right to interfere? Since

\footnotetext{
${ }^{85}$ Thompson, op. cit. supra note 4 , at p. 405.

"Lilienthal, Non-Public Corporations and Ultra Vires (I898) rI HARv. L. REv. 387. See also Whitney Arms Co. v. Barlow (I875) 63 N. Y. 62.

"State v. Essex Bank ( 1836$) 8 \mathrm{Vt} .489$.

${ }^{\text {B }}$ See cases collected, 2 Morawetz, Private Corporations (2d ed. r888) 984, notes 2 and 3 , and 985 , note $I$.

See Gray, J., Leslie v. Lorillard (I888) I Io N. Y. 519, 531, x8 N. E. 363, 365.
} 
the corporation would usually have the right to amend its charter and then engage in the otherwise forbidden activity, the only fault on the part of the corporation is the failure to record an amended charter. Forfeiture for a technical omission of the nature here involved is a harsh and unscientific penalty to impose.

\section{It Violates the Interests of Creditors}

The violation of the interests of creditors can hardly be urged as a sufficient ground upon which to rest the doctrine of ultra vires. It is probably the law that the creditor has no right to complain of an ultra vires transaction unless his security is endangered. ${ }^{00}$ This is a right that should exist independently of any doctrine of ultra vires. It would hardly seem justifiable to establish for the benefit of creditors a doctrine which would result in annulling a contract deliberately entered into, when the creditors' own interest is considered insufficient to entitle them to direct relief. In fact the courts have not seriously treated the creditors' interest as requiring the doctrine of ultra vires for its proper protection.

\section{It Violates the Rights of Stockholders}

Is the fact that an ultra vires transaction is a violation of the rights of the stockholders a sufficient basis upon which to rest the doctrine of ultra vires? It must be admitted that the stockholders are the persons who are most vitally interested in the corporation's risk when it enters in ultra vires transactions, for it means embarking in an enterprise not contemplated in the articles of incorporation. If the officers of the corporation enter into an ultra vires contract without the assent of the stockholder they violate his contract. For this he has his remedy. $\mathrm{He}$ may sue the officers for breach of contract. If the contract has not been entered into but is about to be made he can enjoin the officers. These remedies he has without resorting to the doctrine of ultra vires.

Should his remedy go further and relieve the corporation on the contract in order to further protect him? If the one who contracts with the corporation knows of the limitations upon the power of the corporation or if he ought to have known of this limitation, and the stockholder is not assenting, his position is somewhat analogous to that of one who contracts with an agent with knowledge that he is exceeding the limitation upon his authority and he should not be allowed to hold the corporation liable on the contract. But to deny him the right to hold the corporation on the contract does not involve an application of the doctrine of ultra vires. The simple principles of agency or partnership law will suffice to reach that result. A party contracting with an agent with knowledge, actual or constructive, of the limitations upon the agent's

${ }^{\infty}$ Mills v. Northern Ry. (1870) L. R. 5 Ch. App. 621, Warren, op. cit. supra note 54 , at p. $54 \mathrm{r}$. 
power cannot hold the principal liable. The limitation upon the implied powers of partners are effective as against one who knew or ought to have known of the limitations. On the other hand, the party who contracts with an agent or a partner who is acting in excess of limitations on his power but within the range of the power implied from the nature of the business or from custom or usage may hold the principal or partnership liable, provided he does not know of the limitation, for it is not reasonable to charge him with notice. Should not this rule of partnership and agency law be the criterion in corporation law? Why should we invoke a different system of rules from those of the ordinary partnership? The fact that the shares of the corporation are transferable and the stockholders liability is limited does not demand the application of a different rule in this matter. Persons who contract with the corporation ought not at their peril to be required to ascertain the limits of the corporation's power. They should be allowed to hold the corporation liable wherever it is not reasonable for them to be charged with this knowledge. Is there any better place to draw the line as to where it is reasonable to charge them with notice than where the courts have drawn it in case of agency and partnership law? One court has said, "Upon any other principle there would be no safety in dealing with corporations, and the business operations of these institutions would be greatly crippled, while the interests of the stockholders and of the public, and their general usefulness, would be seriously impaired. The officers are appointed by the corporation, and if any loss results to strangers dealing with the corporation from their misrepresentation in matters within the general scope of their duties, it should fall upon the corporation, which is responsible for their appointment, rather than upon parties who have no other means of ascertaining the facts, and must rely upon their assurance or not deal with the corporation at all."91

\section{Estoppel}

As we have seen most of the American courts which uphold the validity of ultra vires contracts do so on the ground that where the plaintiff has performed, and the defendant has received benefits from that performance, the defendant is estopped to deny the validity of the contract.92 The defendant in receiving the goods treats the contract as valid and he ought not now to be allowed to turn around and take an inconsistent position to his own advantage and plaintiff's detriment. So the courts says he is estopped to take that inconsistent position. But is estoppel a sufficient ground to support these ultra vires contracts which under the law are otherwise unsupportable? If the facts existed for a proper basis of estoppel it is clear that if the basis for holding the ultra vires contract is incapacity on the part of the corporation to

"Miners' Ditch Co. v. Zellerbach (1869) 37 Calif. 543, 588.

${ }^{82}$ See cases cited in note 5 I supra. 
make the contract, or illegality of the contract, or because the outsider has notice of the limitations upon the corporation's power to make the contract, estoppel would not serve to make the contract valid. It may be unfair for the defendant who has received performance of the contract by the plaintiff to try to escape performance upon his part, but while receipt of the performance may be said to constitute a representation of an intent to perform the contract it does not constitute a representation of the validity of the contract and clearly in case the plaintiff is the corporation it does not constitute a representation to one ignorant of the truth and therefore one upon which the plaintiff has relied to its detriment. Entering into an agreement affords as much basis for estopping the plaintiff from denying validity to the contract as accepting performance of the contract. But such a doctrine would make all agreements valid. As has been said by one learned judge, "The principle referred to, if sound, is manifestly sufficient to defeat the defense of ultra vires even when interposed against the enforcement of an executory contract; but it must be admitted that in practice it seems to have been applied only where the agreements have been at least partially performed."9s

The true basis upon which to support the ultra vires contract is not estoppel or fairness between the parties but the simple ground that it is a contract between the parties to which there is no valid objection. It needs no support for there is no sufficient ground for treating it as invalid.

\section{JUDICIAL LEGISLATION}

One eminent author raises the objection of judicial legislation as a reason why the courts should not attempt to abandon the doctrine of. ultra vires. He says, "If the question were res integra, the inclination to take this extreme view of the matter would doubtless be very strong; but at this late day a court which takes this position without any affirmative legislative sanction would seem to be almost if not quite guilty of unsurping the function of the legislature."94

Is this view sound? In the first place would discarding the doctrine of ultra vires by the courts constitute judicial legislation? Would a court by allowing an action on the executory ultra vires contract be guilty of judicial legislation? Bear in mind that the further step; a slight one in some jurisdictions, of giving relief on the executory contract practically completes the disintegration of the doctrine. When we consider that all of the American states have at least in some cases made decisions which are only reconcilable with the theory of general capacities and have used language, the consistent application of which would require the enforcement of all ultra vires contracts whether executory

${ }^{23}$ Mason, J., in Harris v. Gas Co. (I907) 76 Kan. 750, 757, 92 Pac. II23, Ir25.

"Machen, op. cit. supra note 5 , sec. 858 . 
or only partially executed, and that that would mean an abandoment of the doctrine of ultra vires, does the criticism seem in point? If a court's decision makes for a sounder precedent, one more consistent with the general body of the common law, and tends to secure greater justice between the parties who are and will be involved in such activities, and does not tend to upset vested rights or unsettle precedents in cognate lines other than those directly overruled, then the decision is highly desirable and it is questionable whether it constitutes judicial legislation. In the second place if it does fall within what is called judicial legislation, the reply is that it is still desirable. If that is judicial legislation then one of the things we most need is more judicious judicial legislation, though it may be undesirable to have the unjudicious sort. If to abandon the doctrine of ultra vires constitutes judicial legislation then I should say that the whole body of the common law which the courts have built up through the centuries is open to that objection.

\section{CONCLUSION}

When corporations came into existence through special act of the legislature it was not inaccurate to conceive of the corporation as an artificial entity deriving its existence and powers from the state, but when corporations are organized under general laws as they are to-day, and persons are permitted to associate themselves together to form a corporation with such power, practically, as they shall provide, this conception becomes noticeably inaccurate. The doctrine of special capacities is harsh and inflexible and the attempt to break away from it while holding to it in part has introduced great confusion into the law, for every time that corporate action which is ultra vires is held valid involves a denial of the doctrine of special capacities and a following of the doctrine of general powers. When, however, the doctrine of general powers is followed there is no logical or proper halting place short of a complete denial of the doctrine of ultra vires. The attempt to stop short has introduced more confusion into the law, necessitating as it does the discovery of some grounds upon which to base such decisions. The theories propounded have been insufficient in themselves and have not been consistently applied. The ground most commonly given, at least aside from incapacity, for holding the ultra vires transaction invalid is illegality, but to treat the ultra vires contract as invalid because of illegality is undesirable from a practical standpoint, unsound theoretically, and does not explain the decisions. The same criticism may be made of treating the ultra vires contract as invalid on the ground that the one who dealt with the corporation is charged with notice of the charter limitations. To deny validity to the contract on the ground that it is opposed to public policy is going too far, for there is no public interest apart from the interest of particular groups of persons which are protected and only properly by a direct right in the persons con- 
cerned. In special cases where the public has an interest better protected by state interference, such as in the care of insurance and banking, the matter is only properly taken care of by special legislation. When it comes to the protection of the special group of persons most interested, namely the stockholders, there is no demand for the doctrine of ultra vires. The rights between the stockholders and the party who deals with the corporation are better and adequately taken care of by the application of the principles of partnership and agency law.

In conclusion I say there is no excuse for continued adherence to the doctrine of ultra vires. It is not based upon any sound theory or demand of public policy. It results in confusion, uncertainty and injustice in the law. Considerations of fair dealing, and freedom in business activities are opposed to it. Particular situations may demand special legislation but in general the principles of the law of agency and partnership provide a more satisfactory solution of the problem involved. 